\title{
Response Paper: Bailey, J.O. "What Happens in "The Fall of the House of Usher"?" American Literature 35.4 (1964): 445- 66. Academic Search Complete. Web. 9 March. 2016.
}

\author{
Baker M. Bani-Khair \\ English Department, Hashemite University, Jordan \\ E-mail: bakribakr@yahoo.com
}

Received: 02-03-2016

Published: 01-07-2016
Accepted: 15-05-2016

doi:10.7575/aiac.ijalel.v.5n.4p.228
Advance Access Published: May 2016

URL: http://dx.doi.org/10.7575/aiac.ijalel.v.5n.4p.228

J. O. Bailey in "What Happens in "The Fall of the House of Usher"?" (1964) explains the possibilities of reading The Fall of the House of Usher from different angles and perspectives. It tackles the way the story is presented to the reader and the approaches Poe uses towards the psychological as well as the gothic perspectives of fear. The author's pivotal point in the article focuses on the main characters of the story such as Roderick, Madeline and the narrator's inwardly and outwardly sense of terror, fear, and haunting. He explains that each one of these characters represents different possibilities, and, therefore, requires approaching the text from multifarious perspectives, such as going back to Poe's autobiographical life and the history of his education, and the knowledge that Poe was exposed to during his life time.

In fact, the author introduces new techniques that give a better reading of The Fall of the House of Usher. He deconstructs the text through giving a new different analytical reading of the story and explaining the layers the story implies in the understanding of the gothic as well as highlighting the theme of "the vampire Lore" in the story, which the author believes that Poe has implicitly used in his story. He thinks it is impossible to say for sure what Poe read, but he believes that The Fall of the House of Usher has much in common with the gothic "features of Vampire lore" Bailey states:

I think it is a safe guess that Poe also read Polidori's The Vampire, which has a six-page introduction to define a vampire and discuss various legends, in legends and literary developments, to a complex "kith and kin" of demonic possession and witchcraft. I think it is impossible to discover what Poe read, but logical to compare his story with typical features of vampire lore. (449)

Having this possibility and the "vampire lore" in mind, Bailey approaches each one of the characters from this specific angle providing a full analysis of the gothic and supernatural aspects, as well as giving the narrator a different logical judgment that enables him to see things differently from the way Roderick does. Bailey then approaches the idea of the 'house' as the center of the story that introduces several suggestions to the gothic structure and meaning of the "haunted house". Additionally, the author brings all supporting examples from the story itself as well as from the resources he consistently refers the reader to.

At the beginning of the article, Bailey emphasizes the point that the there is something mysterious about the story simply because it hides something which cannot be perfectly understood by psychology, science, or common sense. He excludes the possibility of reading the story from one specific angle such as only gothic, supernatural, or psychological, but he rather refers the reader to all of these possibilities, and yet he emphasizes that the hidden reality about it is still deep and concealed. Therefore, he brings his own extensive reading of the story attempting to analyze what is happening in the story.

It is worth mentioning that Bailey is approaching the text form two dimensions. First of all, he analyzes the associations, implications and symbols that Poe uses in the story referring to the gothic as an outside representation of evil, sickness, death, and fear, and then he also approaches the characters from a psychoanalytical perspective through referring to madness and mental sicknesses. He thus uses a psycho-gothic explanation of the visible as well as the invisible sides of the story. He even considers the House as both a demon and a tomb, and in some other places, he refers to the house as an evil human being quoting the narrator's words when he describes the windows of the house as "eye-like".

The author's analytical explanation of Poe's techniques and strategies in creating the sense of fear and terror in the story is actually deep and logical, but it is also far away and ambiguous at the same time. He traces the gothic and psychological complexity of the story through referring to Roderick's madness as being both gothic and psychological, raising the possibility of reading the text from different ways. Bailey brings "the vampire" image throughout the whole article, and then he extensively builds his argument upon this image. In short, Bailey is suggesting that The Fall of the 
House of Usher is another version of a vampire story which Poe brings from his own imagination as well as from his broad knowledge of the "Vampire Lore".

Despite the fact that Bailey leaves much space for the reader to think of what actually happens in the story, he draws the reader's imagination to one possible reading. The idea of Roderick as a vampire, and the possibility that Poe has read much about "vampires", restricts the reader's imagination and limits the number of possibilities that the story might, probably, entails. While he focuses on Madeline's and Roderick's characters from different perspectives, he seems to see Roderick Usher as Poe himself. He definitely brings Poe's life into the story he analyzes. I think that this could seriously add more complexity to the text, in addition to the fact that the text is not necessarily a presentation of the writer's world. He explains that the Fall of the House of Usher represents "Poe's search for identity". I think that referring to Poe as Roderick Usher, and bringing examples from Poe's psychological problems to fit into the text, gives a narrow and awkward analysis of the story, he says:

To the extent that the present reading is valid, it has, I think, some biographical significance. Roderick Usher is often called a self-portrait of Poe, illustrating his split personality. But in the present reading, Roderick's fear is justified, and there is little split in his personality. Yet the "barely perceptible fissure" in the face of the house seems to symbolize something perhaps a split between the two sides of Poe's nature represented by Roderick and the narrator. (465)

I think that Bailey tries to create a logical and reasonable balance in his explanation of what actually happens in The Fall of the House of Usher. The author mixes psychoanalysis with supernaturalism through the contrast he makes between Roderick and the narrator, and then through Roderick and Poe himself. He thinks that in order to understand what actually happens in the story, one need to analyze both sides of the story. He depends heavily on the narrator to explain the diabolical and evil elements we see in the house, such as the characters and the gothic nature of Roderick's sickness. He also goes back to Roderick to explain the superstitious as well as the gothic nature of his unexplainable and mysterious sickness. Then he also refers to Poe in his attempt to analyze the fissure in the house as being a real "Schizophrenia" which Poe experiences as real psychological problem.

The author actually uses "question and answer "technique in order to decompose the complexity of the story. So, he divides his article into questions and answers. He gives a full analysis for each answer. Every question helps understand the story better because it guides the reader to some important points that might be difficult to understand. Each one of these questions actually pertains to different theme and topic. In each answer he provides his own analytical view relying on the resources he uses, but he also goes back to different resources about Poe's life, and the use of the" vampire lore" and "demonic possession" in the story.

Finally, I think that the writer has successfully given a full length analysis of the story from his point of view and relying heavily on the idea that Poe read and believed in vampires. The questions he provides are really helpful and important in understanding the story. One of the interesting things in this article is that the writer has given us a new possibility of reading the story by having the "vampire lore" in mind. However, it seems difficult to understand what the author talks about here when he refers to "vampire stories", novels and poems through referring to different figures, writers and critics. I think that one actually needs to go back to these resources in order to make connections to Poe's story.

The writer's style, approach, techniques have all shown his deep understanding of the story and the gothic in general. His simple "questions and answers" techniques as well as his deep analysis of the story help the reader understand the story much more profoundly.

\section{Reference}

Bailey, J.O. (1964). What Happens in "The Fall of the House of Usher?". American Literature, 35(4), 445-66. Academic Search Complete. Web. 9 March. 2016. 